\title{
Higher-order Thinking Skills (HOTS) based reading exercises in an EFL textbook for the second-grade students of senior high school Nurul Walikhtira Pratiwi ${ }^{1}$, Ujang Suparman ${ }^{2}$, Burhanuddin ${ }^{3}$ \\ Universitas Lampung, Jl. Prof. Dr. SoemantriBrojonegoro No.1 Bandarlampung, Indonesia ${ }^{1,2,3}$ \\ ${ }^{1}$ Correspondence: nurulwp05@gmail.com
}

\begin{abstract}
The objective of this research was to find out whether reading exercises in an EFL textbook for the second-grade students of senior high school are in accordance with HOTS indicators. This research adopted qualitative descriptive research and content analysis method. The object of this research was the reading comprehension essay questions in the Bahasa Inggris SMA/MA/SMK/MAK Kelas XI textbook published by the Ministry of Education and Culture in 2018. The items of the essay reading questions were analyzed using the cognitive levels of the revised Bloom's taxonomy. As the result, the researcher found that the questions categorized as HOTS level obtain 63 out of 94 questions (67\%). Meanwhile, 31 out of 94 questions (33\%) were categorized as LOTS level. It indicated that this textbook concentrated more on higher-level thinking questions since the most dominant level in the textbook was higher order thinking skills (HOTS).
\end{abstract}

Keywords: higher-order thinking skills (HOTS), lower-order thinking skills (LOTS), textbook, reading comprehension.

\section{INTRODUCTION}

Education becomes an essential part of human beings since it brings a lot of advantages. It gives us knowledge of what is happening around us and changes it into something better. According to Muhammad (2016), education is a simple process of learning and knowing. Having educational experiences helps people to feel, think, and behave which can contribute to someone's success and improve satisfaction in a community. It is also expected that people can learn and explore the world freely. In brief, education can come from anywhere as long as it helps us to learn more about living as human beings.

Education is one of the most important things people should have for a living. In the area of education, it involves the activity of teaching and learning based on the curriculum provided. Mulenga (2018) states that a curriculum is a set of subjects that is taught in schools. In line with the previous statement, Curriculum 2013 was arranged by the Minister of Education and Culture of Indonesia to support the teaching and learning process. The curriculum can be applied in every subject taught in schools, including English. As stated by Kemendikbud (2013), English is one of the main subjects which students have to master.

English is a foreign language that many students find not easy to learn but they are required to master the English four basic skills, including listening, speaking, writing, and reading. Among those skills that students have to master, reading is considered difficult because students are required to combine their own prior knowledge with the information from the context (Anderson, 
2008). Additionally, as stated by Pang et. al. (2003), reading consists of two major processes, word recognition and comprehension. Word recognition refers to the process of perceiving how written symbols correspond to spoken language and comprehension refers to the process of being able to understand words, sentences, and paragraphs.

To overcome the difficulties in reading, there should be learning media to support the teaching and learning process. One of the learning media that can help students to learn is by using textbooks. A textbook is one of the tools that is generally used in the teaching and learning process. O'Keeffe (2013) states that textbooks are widely accepted as the common feature in the classrooms and are important vehicles for the promotion of specific types of curricula. O'Keeffe (2013) also added that not only do textbooks help the students and their learning process, but they also help teachers and their teaching activity by providing frameworks, texts, and tasks. Furthermore, Assaly and Igbaria (2014) claim that textbooks are one of the important aspects in developing students' higher-level thinking processes. The characteristics of a textbook should be designed from lower to higher-order thinking skills (Sukmawijaya et al., 2020). Suparman et al. (2020) also support this by stating reading comprehension involves critical thinking. There is no reading comprehension without using critical thinking (Suparman et al., 2020). Therefore, reading exercises of textbooks should involve students' higher thinking skills when answering questions.

As introduced in Bloom's taxonomy, Higher-Order-Thinking-Skills (HOTS) are reflected by three cognitive domains in Bloom's taxonomy: analysis, synthesis, and evaluation which have been revised by Anderson and Krathwohl (2001) with a focused look at analyzing, evaluating, and creating.

The Ministry of Education and Culture of Indonesia introduced HOTS-based questions for the first time in 2018 during the High School National Examination. Ariyana et al. (2018) claim that introducing HOTS is the government's effort to improve the quality of learning and the quality of graduates. Moreover, by applying HOTS-oriented questions in the National Examination, the government hopes that the students will succeed in achieving various competencies, such as critical thinking, creative and innovative, communication skills, collaboration skills, and self-confidence (Ariyana et al., 2018).

As time goes by, the implementation of higher-order thinking skills based questions started to be applied in various subjects in school to improve the quality of education in Indonesia. Along with it, the use of higher-order thinking skills based questions began to be applied in the schools mid-term and final examination. Furthermore, the teachers are obligated to understand and know more about Higher-Order Thinking Skills (HOTS) and their categories so they will not have any struggle in teaching the students with HOTS-based teaching and learning process.

Therefore, it means that today's book exercise should be based on HOTS, however, it is reported that not all exercises in textbooks are in accordance with the HOTS context. This is suggested by Anasy (2016) that English textbooks should be continuously monitored and checked as one of continuous improvement. Several elements in the textbook need to be evaluated such as textbook 
instructions and teaching materials whether or not they are matched with the indicators of HOTS since HOTS requires the students to think critically than LOTS does.

\section{METHODS}

This study adopted qualitative descriptive research as the data were taken from an EFL textbook. The content analysis method is the method which the researcher used because the researcher analyzed the content of a textbook with focus on the reading comprehension exercises in the textbook for the second-grade of senior high school students. The object of this research is the reading comprehension essay questions which usually show after the reading material in theBahasaInggris SMA/MA/SMK/MAK Kelas XI published by Kemendikbud in 2018. Further, the researcher analyzed the data using a table checklist which has been validated by some experts.

\section{FINDINGS AND DISCUSSIONS Findings}

In this section, the researcher attempts to present the findings of this research. The researcher analyzed the essayreading comprehension questions using a checklist table to find out the distribution of the six cognitive domains in the textbook, whether they meet HOTS' indicators or not.

3.1 The Distribution of Cognitive Domain in Essay Reading Questions from the Main Chapters

\begin{tabular}{|c|c|c|c|c|c|c|c|c|c|}
\hline \multirow{3}{*}{ Ch. } & \multirow{3}{*}{ No. } & \multirow{3}{*}{ Reading Questions } & \multicolumn{6}{|c|}{$\begin{array}{l}\text { Cognitive Domain of } \\
\text { Bloom'sTaxonomy }\end{array}$} & \multirow{3}{*}{ Indicator } \\
\hline & & & \multicolumn{3}{|c|}{ LOTS } & \multicolumn{3}{|c|}{ HOTS } & \\
\hline & & & C1 & $\mathrm{C2}$ & $\mathbf{C 3}$ & $\mathbf{C 4}$ & C5 & C6 & \\
\hline \multirow{3}{*}{4} & 1. & What is global warming? & $\sqrt{ }$ & & & & & & $\begin{array}{l}\text { Remembering, } \\
\text { recall the } \\
\text { information. }\end{array}$ \\
\hline & 2. & Is it a severe problem? Why? & & $\sqrt{ }$ & & & & & $\begin{array}{l}\text { Understanding, } \\
\text { explain the } \\
\text { concept. }\end{array}$ \\
\hline & 3. & What kind of text is given above? & & $\sqrt{ }$ & & & & & $\begin{array}{l}\text { Understanding, } \\
\text { classify the text. }\end{array}$ \\
\hline \multirow{5}{*}{7} & 4. & $\begin{array}{l}\text { What do you think the title "Stand } \\
\text { by Me" means? }\end{array}$ & & $\sqrt{ }$ & & & & & $\begin{array}{l}\text { Understanding, } \\
\text { explain the } \\
\text { concept. }\end{array}$ \\
\hline & 5. & $\begin{array}{l}\text { Do you consider "Stand by Me" } \\
\text { an inspirational song? Why? }\end{array}$ & & $\sqrt{ }$ & & & & & $\begin{array}{l}\text { Understanding, } \\
\text { explain the } \\
\text { identification. }\end{array}$ \\
\hline & 6. & $\begin{array}{l}\text { If you had to change the lyrics of } \\
\text { "Stand by Me", which lyrics } \\
\text { would you change? }\end{array}$ & & & & & & $\sqrt{ }$ & $\begin{array}{l}\text { Creating, change } \\
\text { a thing. }\end{array}$ \\
\hline & 7. & $\begin{array}{l}\text { What do you think is the theme of } \\
\text { this song? }\end{array}$ & & $\sqrt{ }$ & & & & & $\begin{array}{l}\text { Understanding, } \\
\text { explain the } \\
\text { identification. }\end{array}$ \\
\hline & 8. & $\begin{array}{l}\text { Is this an inspiring song? Does it } \\
\text { inspire you? }\end{array}$ & & $\sqrt{ }$ & & & & & $\begin{array}{l}\text { Understanding, } \\
\text { explain the } \\
\text { identification. }\end{array}$ \\
\hline
\end{tabular}




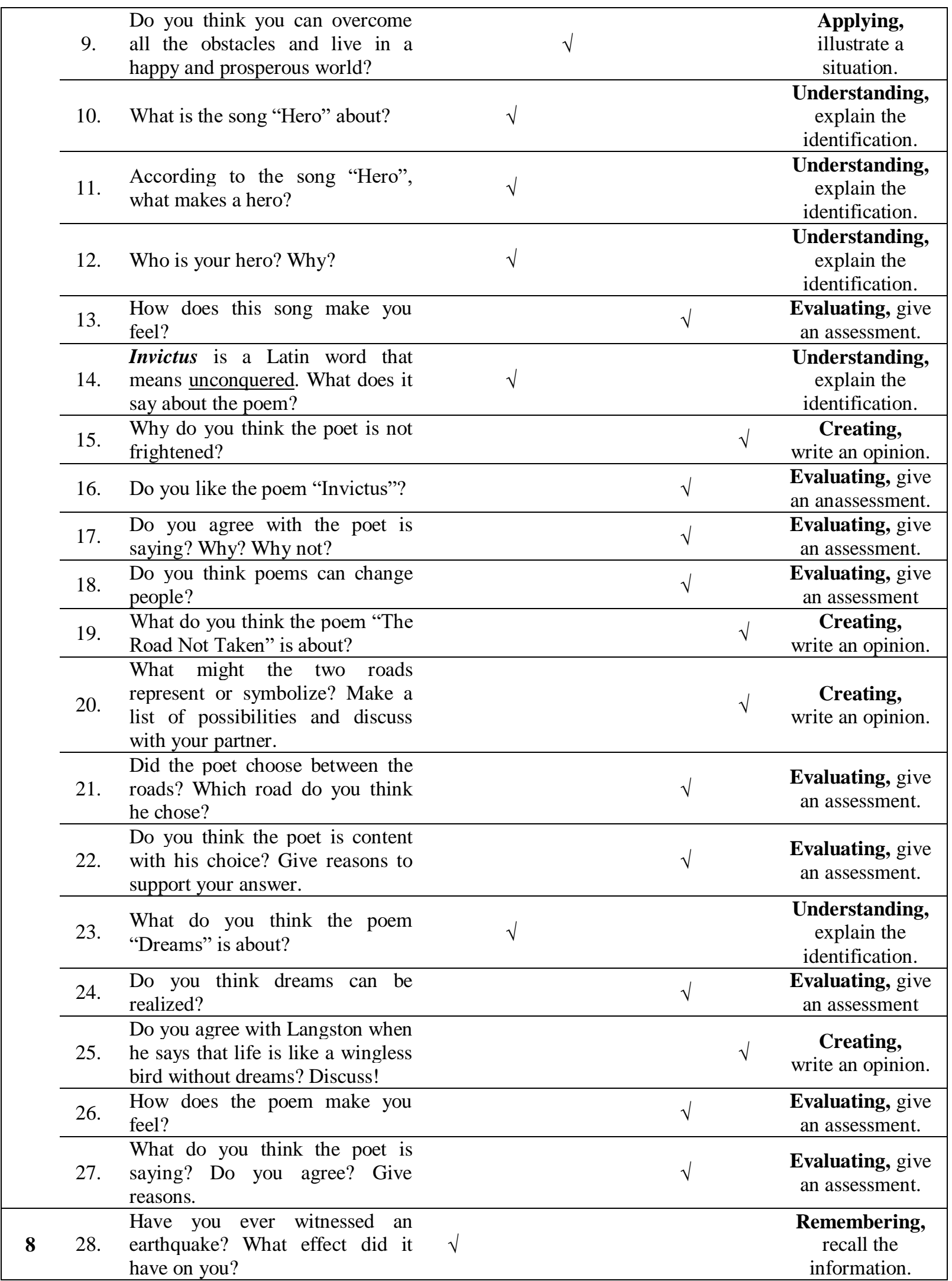




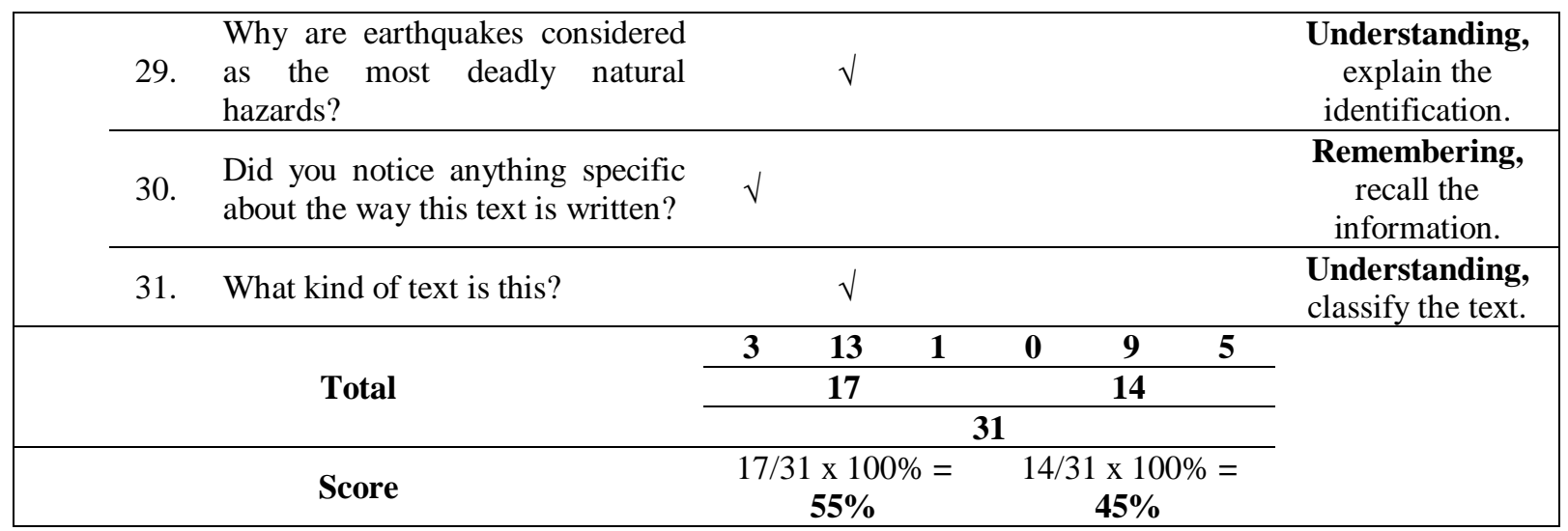

Based on the table above, the distribution of the higher-order thinking level which consists of analyzing, evaluating, and creating skills get 14 questions out of 31 questions. Further, the distribution of the lower-order thinking level consists of remembering, understanding, and applying get 17 questions out of 31 questions. The indicator domain distribution of higher-order thinking level that consists of evaluating skill (C5) gets 9 items and creating skill (C6) gets 5 items, meanwhile, there is no question that belongs to the analyze skill (C4).

Additionally, the indicator domain distribution of lower-order thinking level that consists of remembering $(\mathrm{C} 1)$ gets 3 items and understanding skill (C2) gets 13, meanwhile applying skill (C3) only gets 1 item. The score that can the researcher get from the table above: the score distribution of the higher-order thinking level gets $45 \%$ out of $100 \%$ meanwhile the score distribution of lowerorder thinking level gets $55 \%$ out of $100 \%$. The data show us that the distribution of higher-order thinking level and lower-order thinking level essay reading questions in the main chapters of the textbook do not have much difference. However, the distribution of lower-order thinking level essay reading questions in main chapters are higher than the higher-order think level ones.

\subsection{The Distribution of Cognitive Domain in Essay Reading Questions from theEnrichment Chapters}

\begin{tabular}{|c|c|c|c|c|c|c|c|c|c|}
\hline \multirow{3}{*}{ Ch. } & \multirow{3}{*}{ No. } & \multirow{3}{*}{ Reading Questions } & \multicolumn{6}{|c|}{$\begin{array}{c}\text { Cognitive Domain of Bloom's } \\
\text { Taxonomy }\end{array}$} & \multirow{3}{*}{ Indicator } \\
\hline & & & \multicolumn{3}{|c|}{ LOTS } & \multicolumn{3}{|c|}{ HOTS } & \\
\hline & & & C1 & $\mathbf{C 2}$ & $\mathrm{C3}$ & $\mathrm{C4}$ & C5 & C6 & \\
\hline \multirow[t]{2}{*}{1} & 1. & $\begin{array}{l}\text { Did the fisherman like asking the } \\
\text { fish for wishes? How did he feel } \\
\text { about it? Do you think he could } \\
\text { have done something else instead } \\
\text { of going back to the fish again } \\
\text { and again? }\end{array}$ & & $\sqrt{ }$ & & & & & $\begin{array}{l}\text { Understanding, } \\
\text { explain the } \\
\text { identification. }\end{array}$ \\
\hline & & $\begin{array}{l}\text { The story doesn't reveal how the } \\
\text { prince was turned into a fish. } \\
\text { What do you think might have } \\
\text { happened? }\end{array}$ & & & & & $\sqrt{ }$ & & $\begin{array}{l}\text { Evaluating, give } \\
\text { an assessment. }\end{array}$ \\
\hline
\end{tabular}




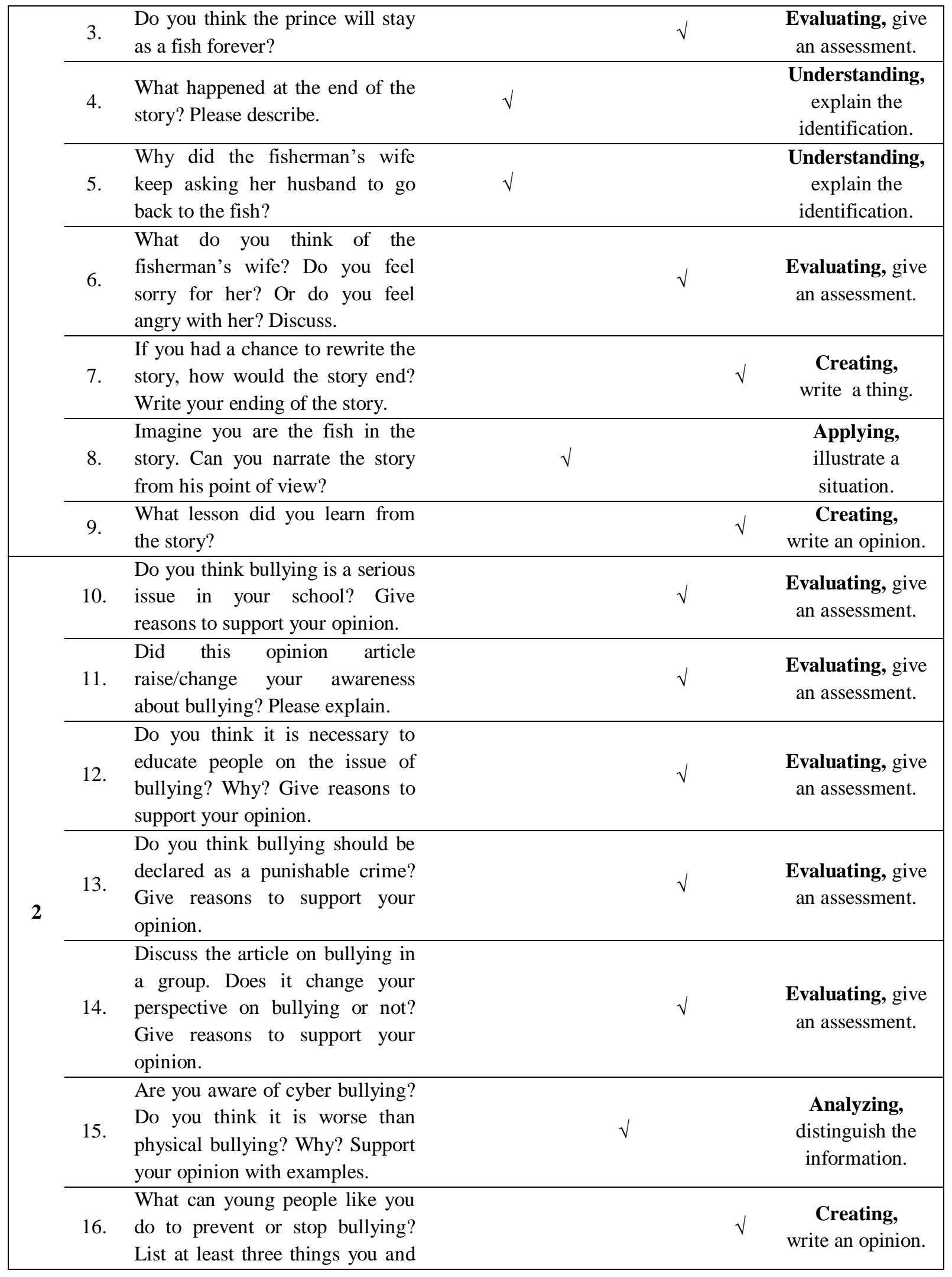




\begin{tabular}{|c|c|c|c|c|c|c|c|}
\hline & & $\begin{array}{l}\text { your friends can do to prevent or } \\
\text { stop bullying. }\end{array}$ & & & & & \\
\hline \multirow{8}{*}{3} & 17. & $\begin{array}{l}\text { Do you think politics has changed } \\
\text { much since the time of President } \\
\text { Sukarno? }\end{array}$ & & & $\sqrt{ }$ & & $\begin{array}{l}\text { Evaluating, give } \\
\text { an assessment. }\end{array}$ \\
\hline & 18. & $\begin{array}{l}\text { Why did President Sukarno want } \\
\text { everyone to be united? }\end{array}$ & $\sqrt{ }$ & & & & $\begin{array}{l}\text { Remembering, } \\
\text { recall the } \\
\text { information. }\end{array}$ \\
\hline & 19. & $\begin{array}{l}\text { What is the new kind of } \\
\text { colonialism that President } \\
\text { Sukarno is talking about? Does it } \\
\text { still exist? If yes, please describe } \\
\text { in what ways. Support your } \\
\text { answers with examples. }\end{array}$ & & $\sqrt{ }$ & & & $\begin{array}{l}\text { Analyzing, } \\
\text { distinguish the } \\
\text { information. }\end{array}$ \\
\hline & 20. & $\begin{array}{l}\text { From this article, can you figure } \\
\text { out President Sukarno's hopes } \\
\text { and dreams for the world? } \\
\text { Explain. }\end{array}$ & & $\sqrt{ }$ & & & $\begin{array}{l}\text { Analyzing, } \\
\text { examine the } \\
\text { information. }\end{array}$ \\
\hline & 21. & $\begin{array}{l}\text { What are your hopes and dreams } \\
\text { for the world and especially for } \\
\text { your country? Describe. }\end{array}$ & & & & $\sqrt{ }$ & $\begin{array}{c}\text { Creating, } \\
\text { write an opinion. }\end{array}$ \\
\hline & 22. & $\begin{array}{l}\text { Do you think President Sukarno } \\
\text { was able to realize his dreams and } \\
\text { hopes? If yes, how? }\end{array}$ & & & $\sqrt{ }$ & & $\begin{array}{l}\text { Evaluating, give } \\
\text { an assessment. }\end{array}$ \\
\hline & 23. & $\begin{array}{l}\text { According to President Sukarno, } \\
\text { peace is very important. What do } \\
\text { you think? Discuss. }\end{array}$ & & & & $\sqrt{ }$ & $\begin{array}{c}\text { Creating, } \\
\text { write an opinion. }\end{array}$ \\
\hline & 24. & $\begin{array}{l}\text { If you were given a chance to } \\
\text { give a speech in front of all the } \\
\text { presidents and prime ministers of } \\
\text { the world, what would you talk } \\
\text { about? Discuss in details. }\end{array}$ & $\sqrt{ }$ & & & & $\begin{array}{l}\text { Applying, } \\
\text { illustrate a } \\
\text { situation. }\end{array}$ \\
\hline \multirow{3}{*}{4} & 25. & $\begin{array}{l}\text { What do you think of Madame } \\
\text { Loisel? Do you know anyone } \\
\text { who has the same personality as } \\
\text { Madame Loisel? How are they } \\
\text { alike? Please describe. }\end{array}$ & & & $\sqrt{ }$ & & $\begin{array}{l}\text { Evaluating, give } \\
\text { an assessment. }\end{array}$ \\
\hline & 26. & $\begin{array}{l}\text { In the beginning of the play, } \\
\text { Madame Loisel was very sad and } \\
\text { unsatisfied. Why was she sad and } \\
\text { unsatisfied? What did she want? } \\
\text { Support your answer with } \\
\text { examples from the play. }\end{array}$ & & $\sqrt{ }$ & & & $\begin{array}{l}\text { Analyzing, } \\
\text { examine the } \\
\text { information. }\end{array}$ \\
\hline & 27. & $\begin{array}{l}\text { Why do you think Madame } \\
\text { Loisel borrowed the necklace } \\
\text { from her friend? }\end{array}$ & & & & $\sqrt{ }$ & $\begin{array}{c}\text { Creating, } \\
\text { write an opinion. }\end{array}$ \\
\hline
\end{tabular}




\begin{tabular}{|c|c|c|c|c|c|}
\hline & 28. & $\begin{array}{l}\text { Do you think she had a good time } \\
\text { at the ball? Support your answer } \\
\text { with examples from the play. }\end{array}$ & $\sqrt{ }$ & & $\begin{array}{l}\text { Evaluating, give } \\
\text { an assessment. }\end{array}$ \\
\hline & 29. & $\begin{array}{l}\text { Do you think Madame Loisel's } \\
\text { longing for higher-class life } \\
\text { ruined her? Support your answer } \\
\text { with reasons. }\end{array}$ & & $\sqrt{ }$ & $\begin{array}{c}\text { Creating, } \\
\text { write an opinion. }\end{array}$ \\
\hline & 30. & $\begin{array}{l}\text { What event brought about the } \\
\text { beginning of a new life for } \\
\text { Monsieur and Madame Loisel? } \\
\text { Did this event change their life } \\
\text { for better or worse? Give seasons } \\
\text { to support your answer. }\end{array}$ & $\sqrt{ }$ & & $\begin{array}{l}\text { Analyzing, } \\
\text { examine the } \\
\text { information. }\end{array}$ \\
\hline & 31. & $\begin{array}{l}\text { Why do you think they didn't tell } \\
\text { Madame Forestier that they had } \\
\text { lost the necklace? Give reasons to } \\
\text { support your answer. }\end{array}$ & & $\sqrt{ }$ & $\begin{array}{c}\text { Creating, } \\
\text { write an opinion. }\end{array}$ \\
\hline & 32. & $\begin{array}{l}\text { Did the ending of the play } \\
\text { surprise you? What kind of } \\
\text { ending did you expect? Explain. }\end{array}$ & $\sqrt{ }$ & & $\begin{array}{l}\text { Evaluating, give } \\
\text { an assessment. }\end{array}$ \\
\hline & 33. & $\begin{array}{l}\text { What is the moral of the story? } \\
\text { Discuss what you learned from } \\
\text { this story. }\end{array}$ & $\sqrt{ }$ & & $\begin{array}{l}\text { Evaluating, give } \\
\text { an assessment. }\end{array}$ \\
\hline & 34. & $\begin{array}{l}\text { If you had a chance to rewrite the } \\
\text { story, how would the story end? } \\
\text { Write a new ending for the story. }\end{array}$ & & $\sqrt{ }$ & $\begin{array}{c}\text { Creating, } \\
\text { write a thing. }\end{array}$ \\
\hline & 35. & $\begin{array}{l}\text { Do you think it is important to } \\
\text { have faith? Why? Give reasons to } \\
\text { support your answer. }\end{array}$ & & $\sqrt{ }$ & $\begin{array}{c}\text { Creating, } \\
\text { write an opinion. }\end{array}$ \\
\hline & 36. & $\begin{array}{l}\text { Do you think it was justified on } \\
\text { Rancho's part to consider the post } \\
\text { office employees as a bunch of } \\
\text { thieves? Discuss. }\end{array}$ & $\sqrt{ }$ & & $\begin{array}{l}\text { Evaluating, give } \\
\text { an assessment. }\end{array}$ \\
\hline 5 & 37. & $\begin{array}{l}\text { Do you think Rancho did the } \\
\text { right thing by asking God for } \\
\text { help? Discuss. }\end{array}$ & $\sqrt{ }$ & & $\begin{array}{l}\text { Evaluating, give } \\
\text { an assessment. }\end{array}$ \\
\hline & 38. & $\begin{array}{l}\text { When people go through difficult } \\
\text { times, they come out of difficult } \\
\text { times stronger and more } \\
\text { experienced. Do you think it is } \\
\text { God's way of empowering people } \\
\text { to fulfill the life's purposes on } \\
\text { earth? Discuss and give reasons } \\
\text { to support your answer. }\end{array}$ & & $\sqrt{ }$ & $\begin{array}{c}\text { Creating, } \\
\text { write an opinion. }\end{array}$ \\
\hline & 39. & $\begin{array}{l}\text { What do you think of Rancho? } \\
\text { Do you sympathize with him and }\end{array}$ & & $\sqrt{ }$ & $\begin{array}{c}\text { Creating, } \\
\text { write an opinion. }\end{array}$ \\
\hline
\end{tabular}




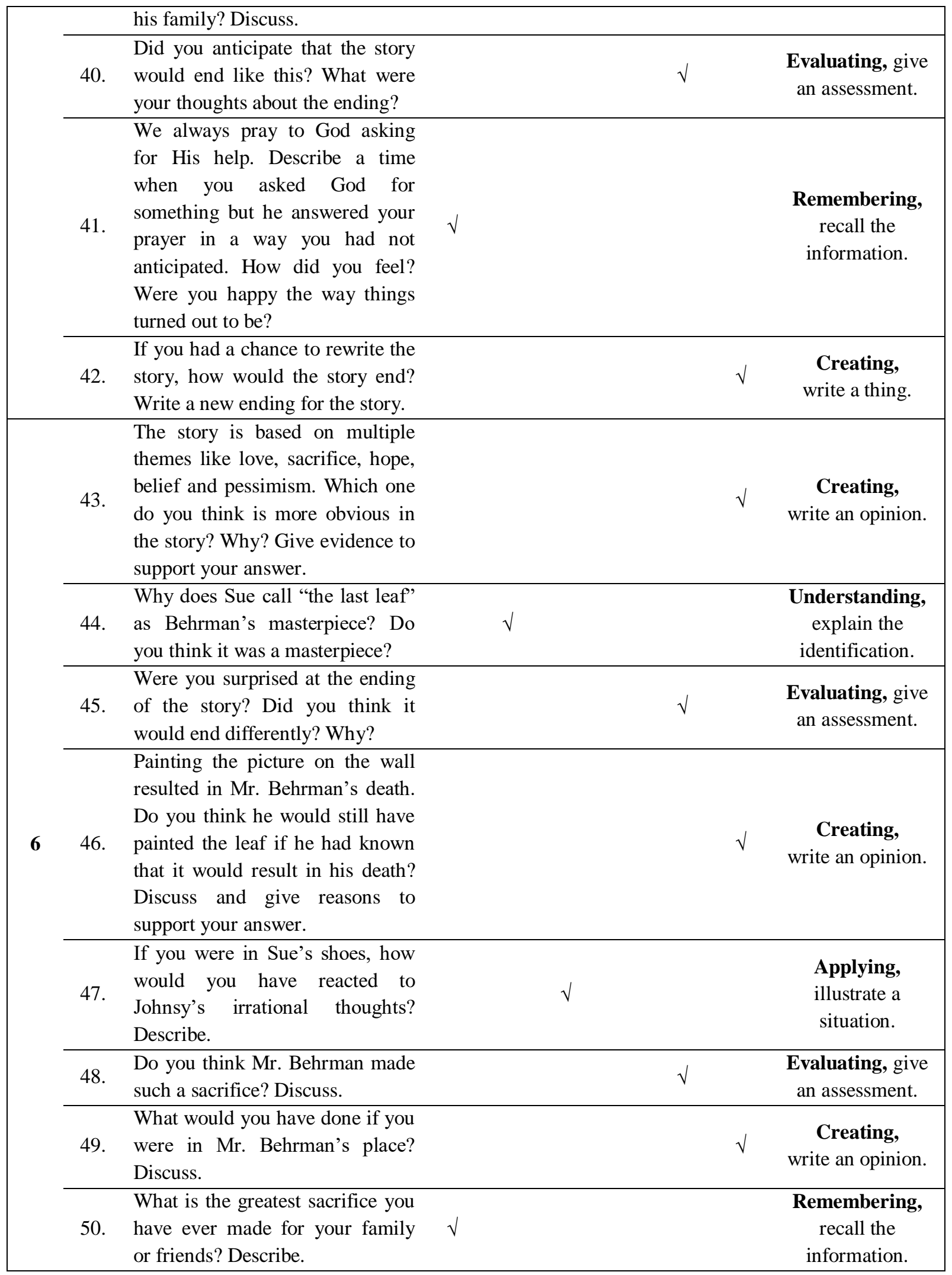




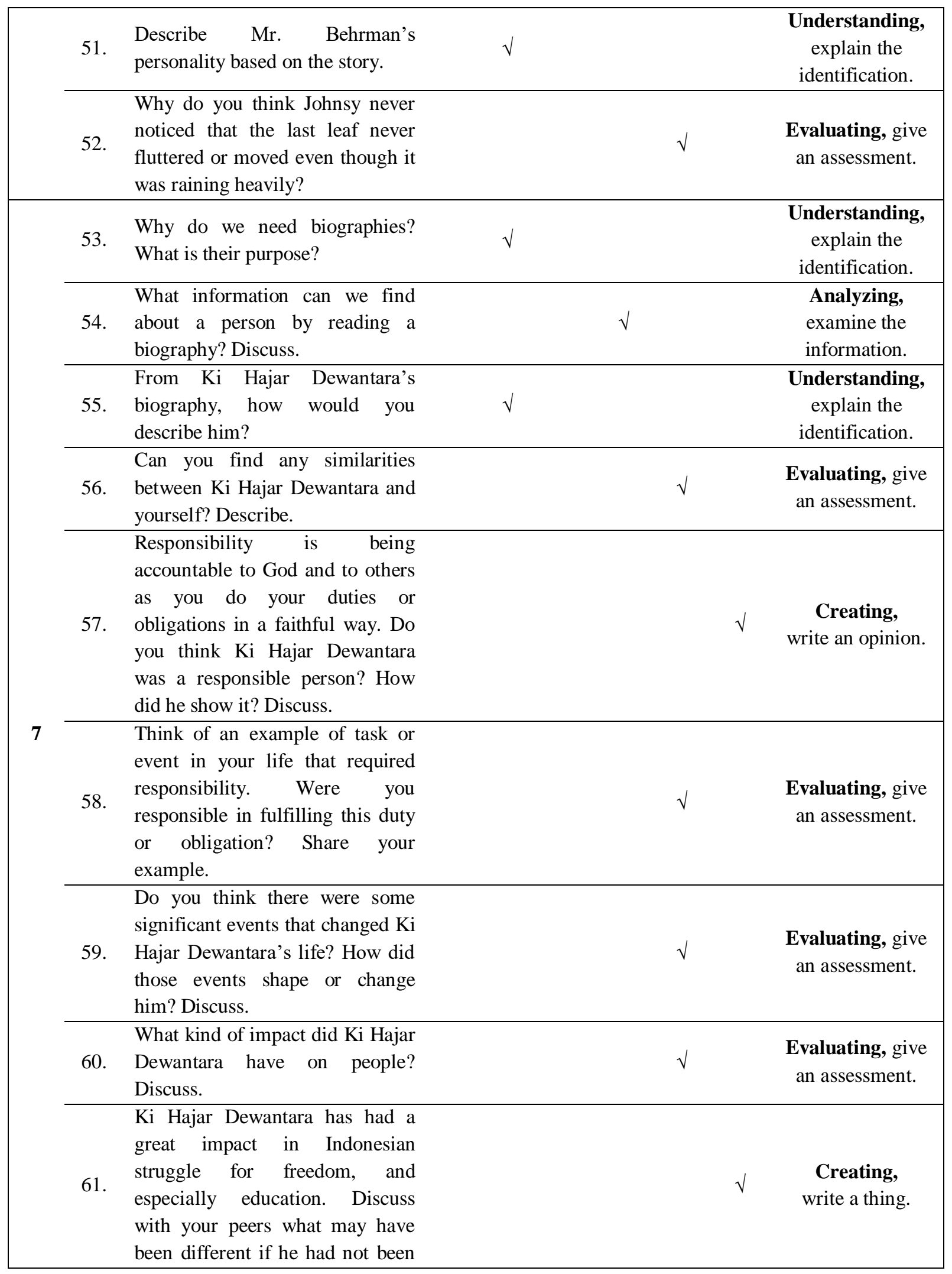




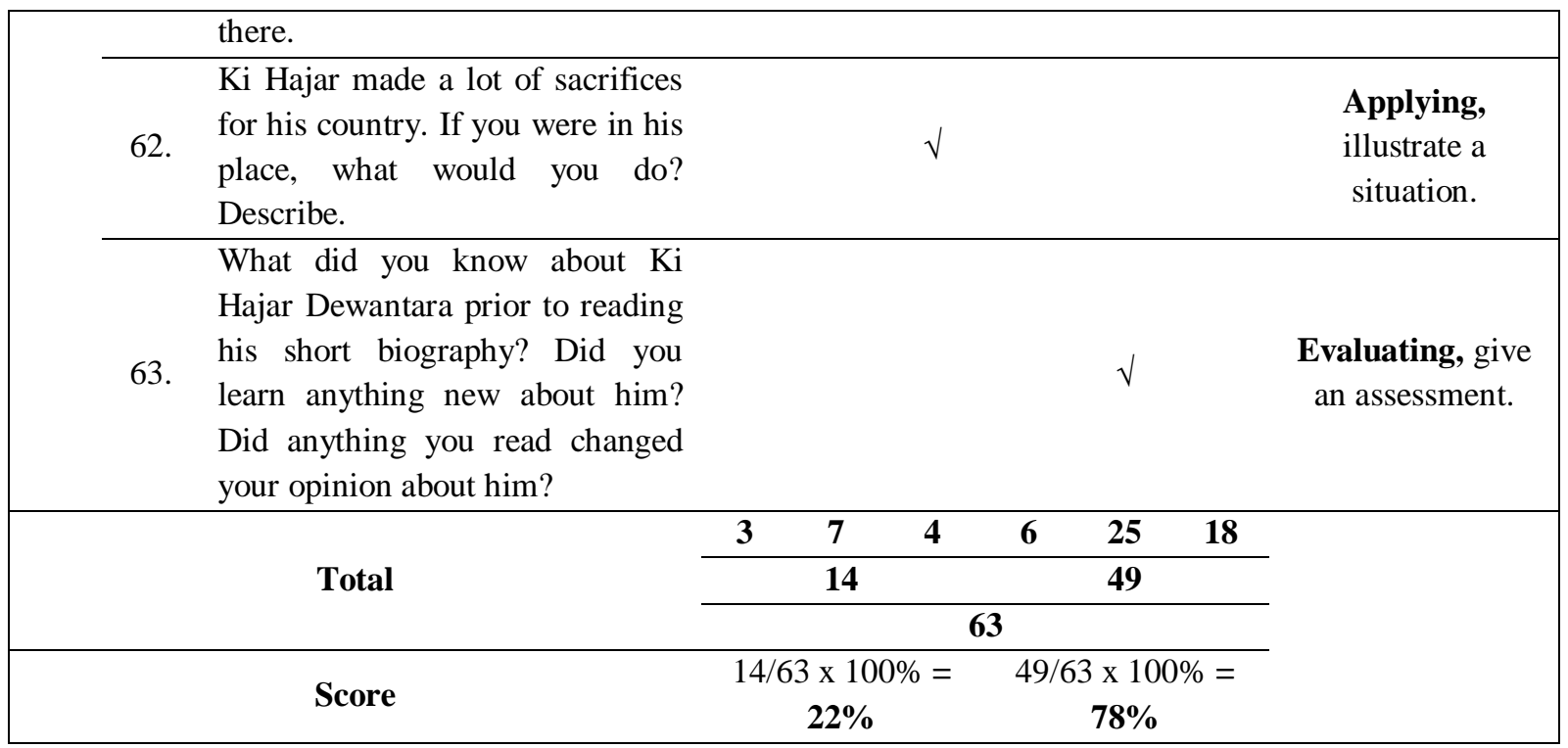

Based on the table, the distribution of the higher-order thinking level which consists of analyzing, evaluating, and creating levels gets 49 questions out of 63 questions. Meanwhile, the distribution of the lower-order thinking level that consists of remembering, understanding, and applying only get 14 questions out of 63 questions. The indicator domain distribution of higher-order thinking level that consists of analyzing skill (C4) gets 6 items, meanwhile evaluating skill (C5) gets 25 items and 18 questions that belong to the creating skill (C6).

Additionally, the indicator domain distribution of lower-order thinking level that consists of remembering $(\mathrm{C} 1)$ only gets 3 items and understanding skill $(\mathrm{C} 2)$ gets 7 items, meanwhile, there are 4 questions that belong to applying skill (C3). The final score that the researcher can get from the table above: the score distribution of the higher-order thinking level gets $78 \%$ out of $100 \%$ meanwhile the score distribution of lower-order thinking level only gets $22 \%$ out of $100 \%$. The results of this table show that there are more higher-order thinking level questions than the questions which belong to lower-order thinking level in the textbook, this is marked by the score obtained by the distribution of higher-order thinking level questions is $78 \%$ and the score obtained by the distribution of lower-order thinking level questions equal to $22 \%$.

Furthermore, the researcher provided a pie chart related to the scores obtained from the distribution of the skills from higher-order thinking levels and lower-order thinking levels. The pie chart below shows the percentage distribution of skill from higher-order thinking level and lower-order thinking level. 


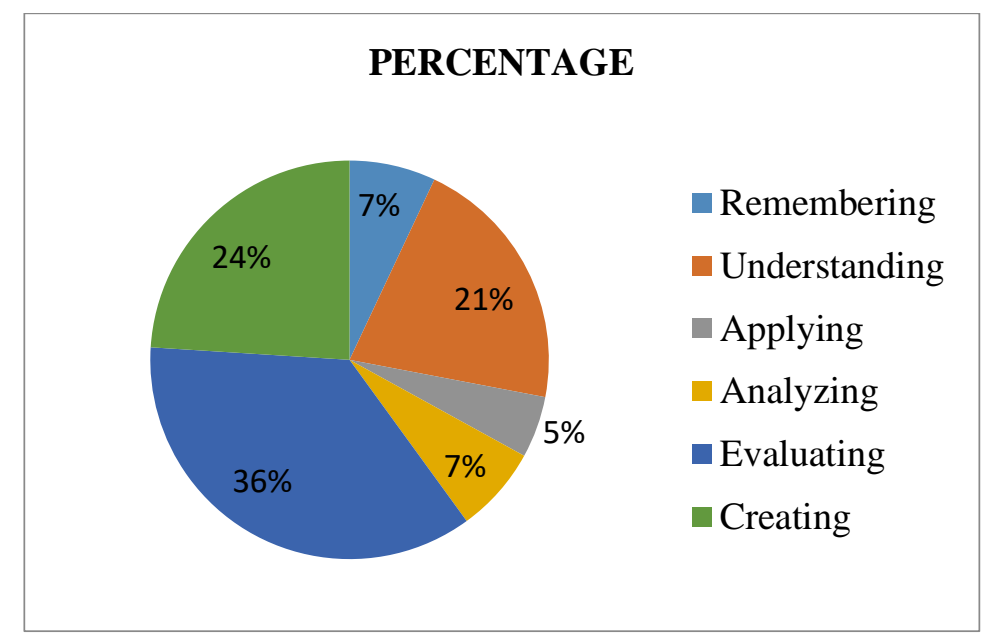

\section{Chart 3.1 The Percentage Distribution of Skills from Higher-Order Thinking Level and Lower-Order Thinking Level}

\section{Discussion}

Higher-order thinking skills-based tests were first implemented in 2018, precisely on the senior high school national examination. The implementation of higher-order thinking skills was also due to the implementation of the new curriculum, Curriculum 2013. With the implementation of higher-order thinking skills, it is expected that students can achieve various competencies. These competencies are critical thinking, creative and innovative thinking, communication skills, collaboration, and confidence.

Hence, it is important to know how good the textbook practices the higher-order thinking skills for the students because as the second-grade students who will continue their study in the university soon, it is better to train their critical thinking so that they could easily go along with the different atmosphere in the teaching and learning process at the university life which is more challenging. Therefore, the writer wants to know the distribution of higher-order thinking level of the essay reading exercise in the Bahasa Inggris SMA/MA/SMK/MAK Kelas XI textbook.

The researcher divided the six skills of lower-order thinking level (remembering, understanding, applying) and the higher-order thinking level (analyzing, evaluating, creating) based on the revised Bloom's taxonomy. The result of the analysis data shows that the higher-order thinking level obtains higher distribution than the lower-order thinking level. It is proven by the result of the data analysis which shows that the higher-order thinking level obtains $67 \%$ out of $100 \%$. Meanwhile, the lower-order thinking level obtains a lower score with $33 \%$.

From 8 main chapters and 7 enrichment chapters in the textbook, there are 94 essay reading questions in the textbook which are divided into 63 questions belong to the higher-order thinking level and the other 31 questions belong to the lower-order thinking level. Thus, the researcher assumes that there is an inequality number in the distribution of the higher-order thinking and lower-order questions in the reading essay questions. However, it is a good result because the Bahasa Inggris SMA/MA/SMK/MAK Kelas XI textbook provides more HOTS-based questions than LOTS-based questions for the students to practice their higher-order thinking level. 
Therefore, based on the data analysis, the researcher can conclude that the essay reading questions in Bahasa Inggris SMA/MA/SMK/MAK Kelas XI textbook by Kemendikbud (2018) is appropriate to use as the learning source in the teaching and learning process because it provides adequate questions that belong to higher-order thinking level. From the total of 94 questions, the highest skill of higher-order thinking skills is the evaluating skill by obtaining 34 questions meanwhile the lowest skill of higher-order thinking level is the analyzing skill by only getting 6 questions.

\section{CONCLUSION AND SUGGESTION}

\section{Conclusion}

After doing the content analysis by using the checklist table as an instrument for essay reading questions, the researcher concludes that the distribution of the higher-order thinking skills is higher than the distribution of the lower-order thinking skill. It is proven by the result of the data which shows that the distribution of the higher-order thinking skills reaches 63 items out of 94 questions or $67 \%$ out of $100 \%$. Meanwhile, the distribution of the lower-order thinking skill obtained 31 items out of 94 questions or about $33 \%$ out of $100 \%$.

Furthermore, as the focus of this research, the distribution of the higher-order thinking skills looks like: (1) the evaluating skill gets the highest score by obtains 34 questions out of 94 questions or $36 \%$, (2) the creating skill gets the second-highest score by obtains 23 questions out of 94 questions or $24 \%$, (3) the analyzing skill gets the lowest score by only obtains 6 questions out of 94 questions or $7 \%$.

Based on the data above, it can be concluded that the essay reading exercises of BahasaInggris $S M A / M A / S M K / M A K$ Kelas XI textbook are mostly included in the higher-order thinking level category since the result of the data shows that the higher-order thinking level obtains $67 \%$, meanwhile, the lower-order thinking level obtains 33\%. It means the textbook is adequate to use in the teaching and learning process.

\section{Suggestion}

The researcher hopes that this thesis could be useful for the teacher, the students, and the other researcher. Here are some suggestions that the researcher wants to deliver:

First, for the teachers, teachers need to be able to use the textbook optimally during teaching and learning process especially in teaching reading because it provides adequate HOTS-based essay reading questions that can help the students in practice their English. Because 31 items out of 94 questions are still in lower-order thinking skills, teachers should learn and practice how to modify the questions to be in higher-order thinking skills type so the students can get $100 \%$ HOTS-based questions in their learning process.Teachers should encourage the students to train their critical thinking or higher-order thinking skills even outside the school so that they can learn how to solve their own problems. Teachers also have to be more creative during teaching in a short time because of the new rules of online teaching and learning process so the students can achieve the basic competencies well.

Second, for the government, the researcher hopes that the government will provide workshops and training about HOTS for teachers to train their skills in making HOTS-based questions. Further, 
there are still many teachers who do not really understand HOTS so the researcher hopes the government can help them.

Third, for the readers, the readers of this research are hoped to get some references or perspectives about the textbook selection, the reading problem, and the importance of higher-order thinking skills in educational or social life. The researcher also hopes the readers could understand more about questions based on higher-order thinking skills by the indicator from Bloom's taxonomy.

\section{REFERENCES}

Anasy, Z. (2016). HOTS (higher order thinking skill) in reading exercise.TARBIYA: Journal Of Education In Muslim Society, 3(1), 51-63.http://dx.doi.org/10.15408/tjems.v3i1.3886

Anderson, L. W. \& Krathwohl, D. R. (2001). A taxonomy for learning, teaching and assesing, a revision of bloom's taxonomy of educational objectives. Addison Wesley Longman.

Anderson, T. (2008). The theory and practice of online learning(2nd ed.). AU Press Canada.

Ariyana, Y., Bestary, R., \& Mohandas, R. (2018). Buku pegangan pembelajaran berorientasi pada keterampilan berpikir tingkat tinggi. Direktorat Jenderal Guru dan Tenaga Kependidikan Kementerian Pendidikan dan Kebudayaan Hak.

Assaly, I.R., \& Igbaria, A.K. (2014). A content analysis of the reading and listening activities in the EFL textbook of master class. Education Journal, 3(2), 24-38.

Kemendikbud. (2013). Permendikbud nomor 81A tahun 2013 tentang implementasi kurikulum dan pedoman umum pembelajaran.

Muhammad, G. (2016). Education system of pakistan problems, issues and its solution (gul muhammad education planning and management allama iqbal open university islamabad). Scribd.https://www.scribd.com/document/332681716/Education-System-ofPakistan-Problems-Issues-and-Its-Solution-Gul-Muhammad-Education-Planning-andManagement-Allama-Iqbal-Open-University-Islamabad

Mulenga, I. M. (2018). Conceptualization and definition of a curriculum.Journal of Lexicography and Terminology, 2(2), 1-23.

O'Keeffe, L. (2013). A framework for textbook analysis.International Review of Contemporary Learning Research, 2(1), 1-13.http://dx.doi.org/10.12785/irclr/020101

Pang, E. S., Muaka, A., Bernhardt, E. B., \&Kamil, M. L. (2003).Teaching reading:Educational practices series. International Bureau of Education.

Sukmawijaya, A., Yunita, W., \& Sofyan, D. (2020). Analysing higher order thinking skills on the compulsory english textbook for tenth graders of indonesian senior high schools. JOALL (Journal of Applied Linguistics and Literature), 5(2), 137-148. https://doi.org/10.33369/joall.v5i2.10565 
Suparman, U., Hariri, H., Haenila, E.Y., \& Usman, M. 2020. Completely randomized block design for assessment of the gender and personality effect on reading comprehension ability. Journal of Southwest Jiaotong University, 55(4), 1-14.https://doi.org/10.35741/issn.0258$\underline{2724.55 .4 .21}$ 